\title{
Preface to Open Access and the Humanities: Contexts, Controversies and the Future
}

\section{Citation}

Suber, Peter. 2014. Preface to Open access and the humanities: context, controversies and the future, by Martin Paul Eve. Cambridge: Cambridge University Press.

\section{Published Version}

doi:10.1017/CB09781316161012.001

\section{Permanent link}

http://nrs.harvard.edu/urn-3:HUL.InstRepos:13479092

\section{Terms of Use}

This article was downloaded from Harvard University's DASH repository, and is made available under the terms and conditions applicable to Other Posted Material, as set forth at http:// nrs.harvard.edu/urn-3:HUL.InstRepos:dash.current.terms-of-use\#LAA

\section{Share Your Story}

The Harvard community has made this article openly available.

Please share how this access benefits you. Submit a story.

\section{Accessibility}




\section{University Publishing Online}

http://universitypublishingonline.org

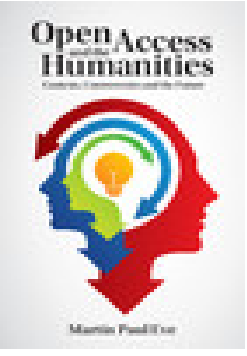

Open Access and the Humanities

Contexts, Controversies and the Future

Martin Paul Eve

Book DOI: http://dx.doi.org/10.1017/CBO9781316161012

Online ISBN: 9781316161012

Hardback ISBN: 9781107097896

Paperback ISBN: 9781107484016

\section{Chapter}

Preface pp. ix-xi

Chapter DOI: http://dx.doi.org/10.1017/CBO9781316161012.001 


\section{Preface}

Open access benefits the sciences and humanities about equally, but has been growing faster in the sciences. That may seem odd until we realise that benefits aren't the only factors affecting growth. Sunlight benefits all plants about equally, but some plants live in dry climates, some at high altitudes, some in rocky soil.

Open access (OA) helps readers find, retrieve, read and use the research they need. At the same time, it helps authors enlarge their audience and amplify their impact. Those are the main benefits. But these benefits lead to others. If OA helps readers and authors of research, then it helps advance research itself and all the benefits that depend on research. In the case of the sciences, that can mean new medicines and useful technologies, and in the case of the humanities it can mean enriched education, politics, compassion, imagination and understanding.

One of the most compelling arguments for legislated OA policies is that governments should assure public access to the results of publicly funded research. This argument is widely effective because it aims to accelerate the research we've already decided to fund with public money, increase the return on the public's large investment in research, and improve fairness to taxpayers. There's no downside for the public interest, only an incomplete upside. There is more public funding for scientific research than for humanities research. Far more. Call this a dry climate for the humanities.

Journals in the humanities have higher rejection rates than journals in the sciences. This is not because they are more rigorous, but because they cover wider topics and receive correspondingly more submissions per published paper. In any case, their higher rejection rates affect their ability to charge fees to cover the costs of production. (Charging 
these fees is the best-known but not the most common business model for OA journals.) If someone on the author side of the transaction, such as the author's employer or funder, pays an article processing charge, then no one needs to pay on the reader side, and the work may become OA. But the fee for an article must cover the costs of vetting all the articles rejected for every one accepted. Hence, fee-based OA journals with high rejection rates must charge higher fees than other journals. The fee-based model works best in well-funded fields with relatively low rejection rates, and worst in fields like the humanities. This is a dry climate combined with the difficulty of transplanting a misty-climate crop to a dry climate.

Journal articles tend to be primary literature in the sciences and secondary literature in the humanities. In the sciences, books tend to synthesise research published in articles, while in the humanities articles tend to report on the history and interpretation of books. Tenure in the sciences depends more on published articles than on books, while tenure in the humanities depends more on published books than on articles. This would just be an observation about disciplinary differences if it weren't for the inconvenient fact that OA for books is objectively harder than OA for articles. The production costs of a book are significantly higher than the production costs of an article. Hence, it's significantly harder to find the business models or subsidies to pay for OA books than those to pay for OA journals. To top it off, academic monographs can pay royalties, in theory, even if they seldom do so in practice. By contrast, scholarly articles never pay royalties, which is the main reason why the worldwide OA movement has focused on articles. Hence, author consent for OA is easier to win for articles than for books.

Despite these obstacles, OA for books is feasible and growing, thanks to many innovative start-ups including the Open Library of Humanities, founded by Martin Eve and Caroline Edwards. However, even progress for OA books doesn't change the fact that scholars in the humanities have reasons to publish in genres where $\mathrm{OA}$ is more difficult, like farmers with reasons to plant higher up the mountainside.

I'll add one more difference between the disciplines and then stop. Certain myths and misunderstandings about OA are more tenacious and widespread in the humanities than in the sciences. This adds 
needless obstacles to the growth of OA. For example, by percentages more humanists than scientists believe that publishing in a highprestige non-OA journal rules out making the same work OA through an online repository, that even well-implemented OA risks copyright infringement, that most OA journals charge author-side fees, that most fees at fee-based OA journals are paid by authors out of pocket, that most non-profit society publishers fear and shun OA, and that most OA publishers are lax with quality control.

I'd like to think that these myths and misunderstandings are more common in the humanities merely because humanists have had less time than scientists to catch up with the relatively recent advent of OA. But that's not true. They've had exactly as much time. Nor is the explanation that humanists are more careless readers of contracts, policies, statutes, or studies of OA itself. I suspect the true explanation is that humanists have had fewer working examples of OA to prove the concept and prove that the sky does not fall. They've had fewer working examples to dispel misunderstandings, generate enthusiasm and inspire commitment. If so, then the humanities labour within a vicious circle in which the slower growth of OA causes a slower growth of good understanding, and vice versa. By contrast the sciences enjoy a virtuous circle in which the faster growth of OA causes a faster growth of good understanding, and vice versa. This is rocky soil for the humanities.

But the same explanation contains a ground for hope. There was a time when the growth of OA in the sciences was also slow, and kept slow by a vicious circle. In fewer than twenty years, however - long in internet time, short in the history of scholarship - the vicious circle in the sciences became a virtuous circle. This reversal is not logically impossible. It requires steady growth in working examples, to feed understanding, and steady growth in understanding, to feed working examples.

The good news is that we see this growth today in the humanities. Martin Eve is among the leaders in making this happen. He's a leader in providing working examples, and a leader in correcting myths and misunderstandings, without underestimating genuine difficulties, through his articles, blog posts, public speaking and now through this book.

PETER SUBER

DIRECTOR, OFFICE FOR SCHOLARLY COMMUNICATION HARVARD UNIVERSITY 